Section Editors

David C. Spencer, MD

Steven Karceski, MD

Steven Karceski, MD

\title{
Early Parkinson disease and depression
}

In the article "The impact of depressive symptoms in early Parkinson disease," Dr. Ravina and colleagues highlight the important association between Parkinson disease (PD) and depression. ${ }^{1}$ Many studies show that up to $50 \%$ of people with PD are depressed. In many studies, these people are already on medication. Medications can sometimes cause depression as a side effect. Dr. Ravina eliminates this concern by studying a large group of people with early PD. In this group of 413 people, no one was yet on a medicine for PD.

Dr. Ravina gathered data from two NIHsponsored clinical trials. In these trials, all of the patients were screened for depression. They used the 15-item Geriatric Depression Scale (GDS-15) to screen the patients for depression. On this scale, a higher number means that a person is more depressed.

They found that over one-fourth $(27.6 \%)$ scored positive for depression on the 15-GDS. Of this group, 25\% were already being treated for depression. The people who were already being treated had higher scores on the 15-GDS. In other words, they were more likely to be depressed.

Almost one-half $(40 \%)$ of this group were not treated for their depression. They were not referred to a psychiatrist for evaluation. One reason for this is that depression is under-recognized. Other studies have shown this as well. A second reason may be that some of the symptoms of early PD are the same as those of depression.

For instance, many people with PD report tiredness. This is a common symptom in depression as well. In other words, a physician may think that the symptoms of depression are actually due to PD. Because of this, he or she would treat the PD. This article proves this as well. People with depression and PD were more likely to be on medication for their PD.

Other studies have suggested that depression is linked to movement problems. Worsening depression in these studies also meant more significant motor difficulties. Ravina et al. analyzed this association carefully. They used specific mathematical tests. Using these tests, they did not find the same association.

This was an important finding because the people with PD and depression reported poor motor skills more often than those who were not depressed. If the depression did not cause the motor problems, then why did this group report being worse off? The answer is simple. Because they were depressed, they reported their symptoms as more severe than the nondepressed group. In other words, their problems were not necessarily worse. They saw them as being worse because of the depression.

WHY IS THIS ASSOCIATION IMPORTANT? This association is important to recognize for several reasons. First, the presence of depression may cause the PD to appear worse than it is. This might cause the physician to start a treatment before it is needed. Second, depression causes poor daily functioning. By addressing the depression, this will improve. Depression occurs often in people with PD. Physicians and patients need to be aware of this association in order to ask the right questions, and begin the best treatments. 
WHAT IS PARKINSON DISEASE? Parkinson disease (PD) is named after James Parkinson. He first described the illness in 1817. PD mostly causes problems with moving around. It can cause a person to move very slowly. A person with PD appears stiff or rigid. At times, a person with PD may appear to suddenly freeze up or be unable to move for a short period of time.

A tremor of the hands is common. It is called a pill-rolling tremor because of how it looks. Many years ago, pharmacists used to make their own tablets. In order to make the medications into a tablet, they would roll the medicine into a small ball. The motion that it takes to roll a small ball looks very similar to the tremor in PD. When a person has $\mathrm{PD}$, he or she often will have one or more of these symptoms.

WHAT CAUSES PARKINSON DISEASE? In PD, the underlying problem has to do with a neurotransmitter called dopamine. A small number of very specific brain cells make dopamine. Though only a few cells make dopamine, these cells send the neurotransmitter to many different regions of the brain. Changes in dopamine levels can have widespread effects within the brain.

When we are young, our brains make plenty of dopamine. As we get older, this amount decreases. In PD, the amount of dopamine becomes critically low. In PD, the amount of dopamine changes very slowly over time. This causes the very gradual worsening of movement. In early PD, as in this study, the symptoms may be mild.

TREATMENT OF PARKINSON DISEASE Understanding the link between dopamine and PD has led to the development of many treatments. The answer seems simple enough: take dopamine. Un- fortunately, the body does not allow dopamine to cross over into the brain where it is needed. This is why people with PD take levodopa. Levodopa can cross over into the brain. The brain converts the medication into dopamine.

There are many other treatments for PD. For the most part, these treatments are aimed at increasing the amount of dopamine in the brain. Other treatments help to keep the dopamine where it is needed most. These treatments maintain the levels of dopamine. By keeping the levels constant, these treatments prevent the motor symptoms from returning.

A physician may not know which treatment is best for a specific person. Every person is different. Some people may require only one medication. Others may need two or more medicines. Physicians must therefore tailor the treatment to the individual.

Although studies can tell us which medicines work, they do not tell us which ones work best for a specific person. Sometimes, more than one medicine must be tried before the best treatment plan can be found. A person with PD can become frustrated if the first treatment does not work. By talking honestly with your doctor, the best treatment can be found.

\section{For more information}

Parkinson's Disease Foundation

http://www.pdf.org

National Parkinson Foundation

http://www.parkinson.org

Michael J. Fox Foundation for Parkinson's

Research

http://www.michaeljfox.org/

1. Ravina B, Camicioli R, Como PG, et al. The impact of depressive symptoms in early Parkinson disease. Neurology 2007;69:342-347. 


\title{
Neurology
}

\author{
Early Parkinson disease and depression \\ Steven Karceski \\ Neurology 2007;69;E2-E3 \\ DOI 10.1212/01.wnl.0000277528.52407.c0
}

This information is current as of July 23, 2007

\section{Updated Information \&} Services

Supplementary Material

References

Permissions \& Licensing

Reprints including high resolution figures, can be found at: http://n.neurology.org/content/69/4/E2.full

Supplementary material can be found at: http://n.neurology.org/content/suppl/2009/08/27/69.4.E2.DC1

This article cites 1 articles, 1 of which you can access for free at: http://n.neurology.org/content/69/4/E2.full\#ref-list-1

Information about reproducing this article in parts (figures,tables) or in its entirety can be found online at:

http://www.neurology.org/about/about_the_journal\#permissions

Information about ordering reprints can be found online:

http://n.neurology.org/subscribers/advertise

Neurology ${ }^{\circledR}$ is the official journal of the American Academy of Neurology. Published continuously since 1951, it is now a weekly with 48 issues per year. Copyright . All rights reserved. Print ISSN: 0028-3878. Online ISSN: 1526-632X.

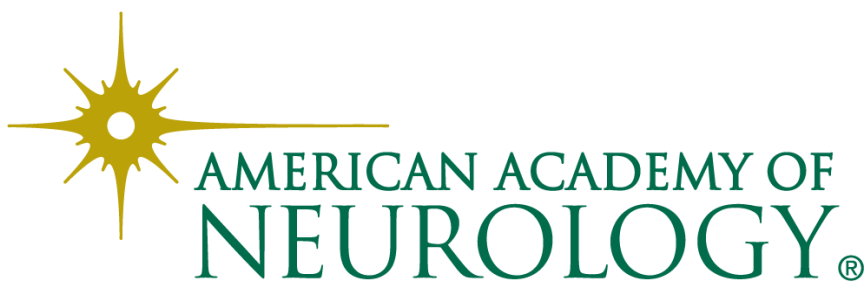

